Printed in Great Britain

\title{
Spermidine in the Bacterial Cell
}

\author{
BY U. BACHRACH AND I. COHEN \\ Department of Clinical Microbiology, Hebrew University-Hadassah Medical \\ School, Jerusalem, Israel
}

(Received 13 September 1960)

\author{
CORRIGENDUM \\ In Work, E. (1961). \\ J. gen. Microbiol. 25, 167-189
}

On p. 169, line 34:

For: 'a solvent which will separate the meso-isomer'

Read: 'a solvent which will separate the LL-isomer'

The polyamines spermidine

and spermine

$\left(\mathrm{NH}_{2}\left(\mathrm{CH}_{2}\right)_{3} \mathrm{NH}\left(\mathrm{CH}_{2}\right)_{4} \mathrm{NH}_{2}\right)$

$$
\left(\mathrm{NH}_{2}\left(\mathrm{CH}_{2}\right)_{3} \mathrm{NH}\left(\mathrm{CH}_{2}\right)_{4} \mathrm{NH}\left(\mathrm{CH}_{2}\right)_{3} \mathrm{NH}_{2}\right)
$$

are widely distributed in nature. They have been found in animal tissues (Dudley \& Rosenheim, 1925; Dudley, Rosenheim \& Starling, 1927; Harrison, 1931; Rosenthal \& Tabor, 1956), in micro-organisms, especially Gram-negative bacteria (Herbst, Weaver \& Keister, 1958; Weaver \& Herbst, 1958), and in some viruses (Ames, Dubin \& Rosenthal, 1958; Bawden \& Pirie, 1959; Ames \& Dubin, 1960). Conjugated polyamines such as acetylated spermidine were found in Escherichia coli (Dubin \& Rosenthal, $1960 a$ ); a spermidine-glutathione conjugate from $E$. coli has also been described (Dubin \& Rosenthal, $1960 \mathrm{~b}$ ). Other conjugates of polyamines have been found in a phospholipid from human malignant tumours (Kosaki, Ikoda, Kotani, Nakagawa \& Saka, 1958) and in spider poisons (Fischer \& Bohn, 1957a).

Very little is known about the biosynthesis of polyamines. The condensation of putrescine with methionine in the presence of adenosine triphosphate and magnesium sulphate has been proposed as a pathway for the biosynthesis of spermidine in Escherichia coli (Tabor, Rosenthal \& Tabor, 1957), and in Neurospora crassa (Greene, 1957). The enzymes involved in this condensation reaction have been purified from E. coli (Tabor, Rosenthal \& Tabor, 1958; Tabor \& Tabor, 1960). Weaver \& Herbst (1958) have found that Haemophilus parainfluenzae produced spermidine from 
propane-1:3-diamine. Quantitative determinations of spermidine in animal tissues were made by Rosenthal \& Tabor (1956) and Fischer \& Bohn (1957 b). Very little, however, is known about the quantities of polyamines found in micro-organisms.

The purpose of the present investigation was to determine quantitatively the amount of spermidine present in extracts of various micro-organisms, to isolate spermidine from different constituents of the bacterial cell, and to study the mechanism of spermidine absorption to the bacterial cell.

\section{METHODS}

Organisms. Strains of the following micro-organisms were used: Bacillus subtilis (ATCC 6633); Pseudomonas aeruginosa (Bachrach, 1957); Escherichia coli 59; Neurospora crassa 34455; Saccharomyces cerevisiae 81. All these strains were from the collection of the Department of Clinical Microbiology, Jerusalem.

Media. Neurospora crassa was grown in the defined medium of Fries described by Nason \& Evans (1953). All the other micro-organisms were grown in the medium of Davis (1949) after adjustment to $\mathrm{pH} 7 \cdot 0$.

Conditions of growth. The micro-organisms were grown in quantities of 1 l. liquid medium in a 3 l. flask agitated on a rotary shaker (New Brunswick Scientific Co., New Brunswick, N.J., U.S.A.). After $20 \mathrm{hr}$. of incubation at $37^{\circ}$ the organisms were harvested by centrifugation (Sharples supercentrifuge, or MSE high-speed centrifuge) and washed three times with physiological saline.

Preparation of cell-free extracts. The micro-organisms were subjected to the action of a $10 \mathrm{kcyc}$. Raytheon sonic oscillator for $25 \mathrm{~min}$. Debris and intact organisms were removed by high-speed centrifugation (13,000 $\mathrm{g}$ for $10 \mathrm{~min}$.).

Preparation of protoplasts. These were prepared according to Fitz-James (1958). Organisms were washed three times with saline and suspended in $0 \cdot 1 \mathrm{M}$-phosphate buffer ( $\mathrm{pH} \mathrm{6 \cdot 1)}$ containing $0.5 \mathrm{M}$-sucrose and $0.016 \mathrm{M}$-magnesium sulphate. Lysozyme $\left(1 \mathrm{mg} . / \mathrm{ml}\right.$.) was then added, and the suspension was incubated at $37^{\circ}$ for $30-60 \mathrm{~min}$. The formation of protoplasts was observed by phase-contrast microscopy. Whole organisms were removed by centrifugation $(3000 \mathrm{~g})$ and the protoplasts separated from the supernatant fluid by a second centrifugation $(10,000 \mathrm{~g})$.

Preparation of cell walls. These were prepared according to Salton \& Horne (1951). Organisms were subjected to the action of a Mickle tissue disintegrator for $60 \mathrm{~min}$. Unbroken organisms were removed by centrifugation $(3000 \mathrm{~g})$ and the cell walls separated by a second centrifugation $(10,000 \mathrm{~g})$. The purity of the preparation was checked by electron microscopy.

Chemicals. Spermidine phosphate was obtained from Hoffman-La-Roche (Basle, Switzerland). Putrescine dihydrochloride, DL-methionine and adenosine triphosphate (ATP), were the products of Nutritional Biochemicals Corp. (Cleveland, Ohio, U.S.A.). 1-Fluoro-2:4-dinitrobenzene was purchased from L. Light and Co. Ltd (Colnbrook, Bucks, England). DL-[2-14 C]methionine was obtained from California Corporation (Los Angeles, U.S.A.).

Spermidine estimations. Paper chromatography was the most convenient method for the qualitative and quantitative estimation of the amines. Butanol +acetic acid + water $(50+25+25$ by vol.; Baker, Harborne \& Ollis, 1952) was the solvent system used. The papers were sprayed with $0.2 \%(w / v)$ ninhydrin in butanol. 
Quantitative determinations were carried out by eluting the coloured complex (Giri, Radhakrishnan \& Vaidyanathan, 1952).

Ion exchange chromatography. A solution of $10 \%(\mathrm{w} / \mathrm{v})$ trichloroacetic acid solution was added to an equal volume of the sample to be examined. The precipitate formed was removed by centrifugation and the residual trichloroacetic acid extracted with ether. Samples of the supernatant fluid were then passed through a column of Dowex $50 \mathrm{H}^{+}(6 \mathrm{~mm}$. diameter; $60 \mathrm{~mm}$. high) and the spermidine eluted from this column by a gradient of $\mathrm{HCl}$ (prepared by the dropwise addition of $2.5 \mathrm{~N}-\mathrm{HCl}$ to $300 \mathrm{ml}$. water in a mixing vessel) at a flow rate of $1 \mathrm{ml} . / \mathrm{min}$. Fractions of $3.5 \mathrm{ml}$. were collected in an automatic fraction collector (LKB-Produkter, Stockholm, Sweden) and the eluate containing spermidine (fraction between 210-270 ml.) was concentrated in vacuum, neutralized and estimated colorimetrically as the 2:4dinitrophenyl derivative (Rosenthal \& Tabor, 1956).

Steam distillation. Samples containing spermidine were steam distilled in a Markham still after the addition of potassium hydroxide (Dudley, Rosenheim \& Rosenheim, 1924).

Protein estimations. Proteins were estimated by the spectrophotometric method of Layne (1957) with a Unicam Model SP 500 Spectrophotometer (Unicam Instruments Ltd, Cambridge).

Radioactivity estimations. Spermidine was identified by paper chromatography and the radioactive areas on the paper were counted either directly with a mica endwindow Geiger-Müller tube, or eluted with water and subsequently assayed for radioactivity by means of an end-window lead-shielded Geiger-Müller tube (Tracerlab). Spermidine was also separated by the ion exchange method, converted into the 2:4-dinitrophenyl derivative, extracted with ethyl acetate and assayed for radioactivity by means of a Geiger-Müller counter.

\section{RESULTS}

Quantitative determinations of polyamines in various micro-organisms

Extracts of micro-organisms obtained after disruption by sonic oscillation were examined for polyamines by paper chromatography. The polyamines detected were separated by the ion-exchange method and assayed colorimetrically. As shown in Fig. 1, 21 $\mu \mathrm{g}$. spermidine were found per mg. protein in an extract of Neurospora crassa. The concentration of spermidine in extracts of Pseudomonas aeruginosa was appreciably lower $(\mathbf{1 2} \cdot 5 \mu \mathrm{g} . / \mathrm{mg}$. protein). The lowest concentration was obtained with Saccharomyces cerevisiae (only $7 \mu \mathrm{g} . / \mathrm{mg}$. protein).

\section{Synthesis of ${ }^{\left[{ }^{14} \mathrm{C}\right]}$ spermidine by growing organisms and by cell-free extracts}

The micro-organisms were grown for $20 \mathrm{hr}$. at $37^{\circ}$, harvested, washed with saline and resuspended in $4.0 \mathrm{ml}$. of medium to which phosphate buffer and $\left[2-{ }^{14} \mathrm{C}\right]$ methionine had been added. After further incubation, the organisms were harvested and disrupted. The spermidine in the extracts was separated by ion-exchange chromatography, and its radioactivity determined. Neurospora crassa contained the highest concentration of $\left[{ }^{14} \mathrm{C}\right]$ spermidine, while the lowest concentration was found in Pseudomonas aeruginosa (Fig. 2).

After ascertaining that growing organisms were capable of producing spermidine 
from putrescine, it was attempted to synthesize this polyamine by extracts obtained from the various micro-organisms. Putrescine, $\left[{ }^{2-{ }^{14}} \mathrm{C}\right]$ methionine, ATP and magnesium sulphate were incubated with the various extracts. The spermidine formed was separated by ion-exchange chromatography and its radioactivity determined. The highest concentrations of $\left[{ }^{14} \mathrm{C}\right]$ spermidine were obtained with extracts of Pseudomonas aeruginosa (Fig. 3).

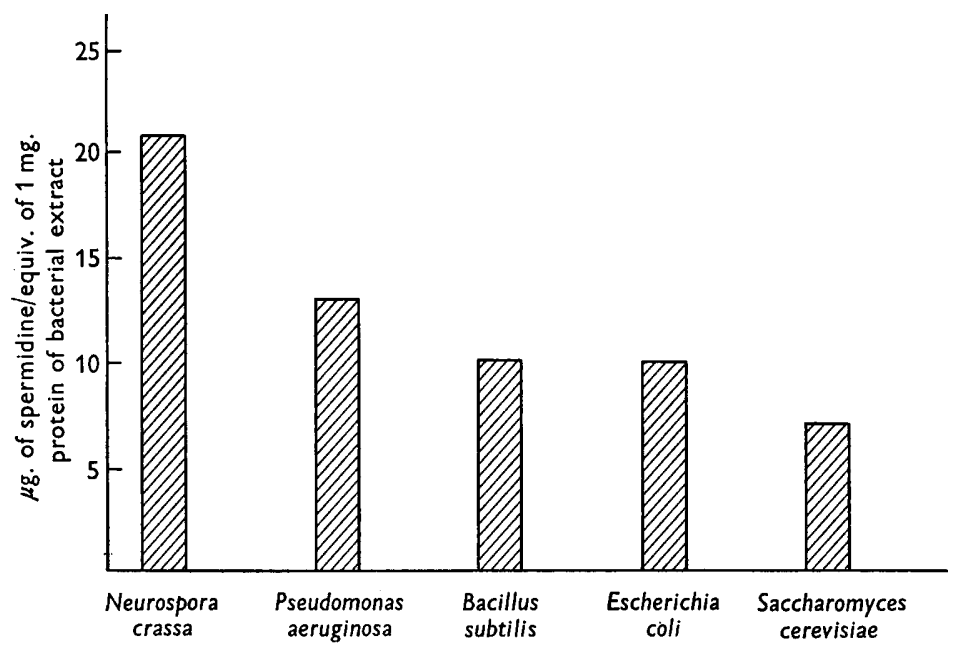

Fig. 1. Spermidine in extracts of various micro-organisms.

\section{Localization of spermidine in Bacillus subtilis}

Bacillus subtilis was chosen for study because of the detailed techniques elaborated for the separation of its cellular constituents. The localization of spermidine in the cell walls and protoplasts was examined by incubating intact bacilli in a medium fortified with either $\left[2-{ }^{14} \mathrm{C}\right]$ methionine or $\left[{ }^{14} \mathrm{C}\right]$ spermidine prepared from $\left[2-{ }^{14} \mathrm{C}\right]$ methionine in the presence of Pseudomonas aeruginosa as described above. B. subtilis was grown in $2000 \mathrm{ml}$. medium at $37^{\circ}$ for $20 \mathrm{hr}$. The bacteria were harvested, washed and

Table 1. $\left[{ }^{14} \mathrm{C}\right]$ Spermidine in cell walls and protoplasts of Bacillus subtilis grown in the presence of $\mathrm{DL}-\left[2-{ }^{14} \mathrm{C}\right]$ methionine or $\left[{ }^{14} \mathrm{C}\right]$ spermidine

Bacteria were grown for $20 \mathrm{hr}$. at $37^{\circ}$, harvested and resuspended in $10.0 \mathrm{ml}$. of medium supplemented with $2.5 \mu$ mole $\mathrm{DL}-\left[2{ }^{-14} \mathrm{C}\right]$ methionine $\left(1.5 \times 10^{5}\right.$ c.p.m. $)$ or $1.0 \mathrm{ml}$. of $\left.{ }^{14} \mathrm{C}\right]$ spermidine $\left(5 \times 10^{3} \mathrm{c} . \mathrm{p} . \mathrm{m}\right.$.) and incubated for another $14 \mathrm{hr}$. The $\left[{ }^{14} \mathrm{C}\right]$ spermidine in the cell walls and protoplasts of these bacteria was determined.

$$
\text { mg. of } \mathrm{mg} \text {. of }
$$$$
\text { protein } / \mathrm{ml} \text {. dry wt. } / \mathrm{ml} \text {. }
$$

$$
\text { of of }
$$

c.p.m./ml.

$$
\text { of }
$$

\begin{tabular}{|c|c|}
\hline Protein & Dry wt. \\
\hline $2 \cdot 400$ & 206 \\
\hline $1 \cdot 225$ & 105 \\
\hline 84 & 42 \\
\hline 71 & 36 \\
\hline
\end{tabular}

Preparation preparation preparation

Cell walls incubated with:

$\left[{ }^{14} \mathrm{C}\right]$ Methionine

$\left[{ }^{14} \mathrm{C}\right]$ Spermidine 
resuspended in $10 \mathrm{ml}$. of medium to which $\left[2-{ }^{14} \mathrm{C}\right]$ methionine had been added. After another $14 \mathrm{hr}$. of incubation the bacteria were again harvested and protoplasts and cell walls prepared. The $\left[{ }^{14} \mathrm{C}\right]$ spermidine in the samples was separated by steam distillation. The distillate was concentrated and examined by paper chromatography.

The amount of $\left[{ }^{14} \mathrm{C}\right]$ spermidine bound to an equivalent of $1 \mathrm{mg}$. dry wt. of the cell wall was higher than that bound to the same equivalent of protoplast. The amount of $\left[{ }^{14} \mathrm{C}\right]$ spermidine localized in the cell walls of Bacillus subtilis was also higher when $\left[{ }^{14} \mathrm{C}\right]$ methionine was added to the growing organisms (Table 1 ).

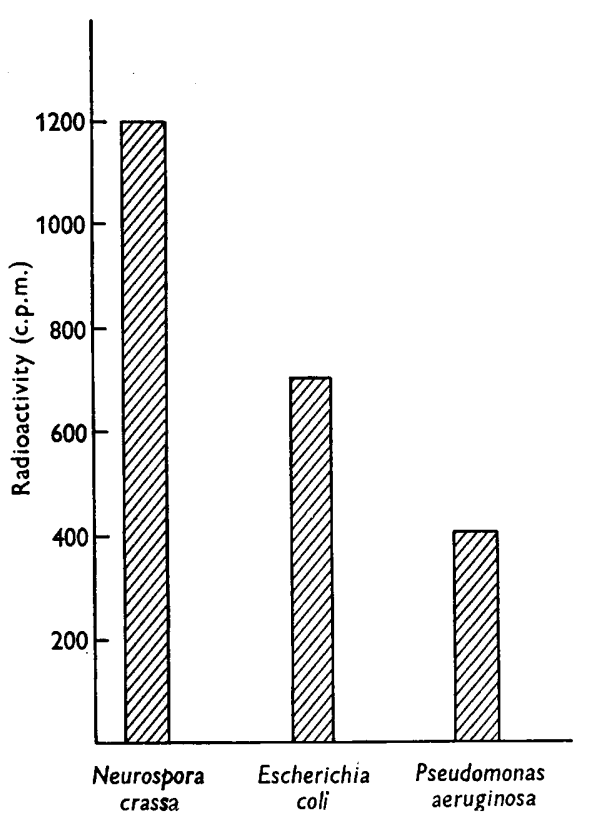

Fig. 2

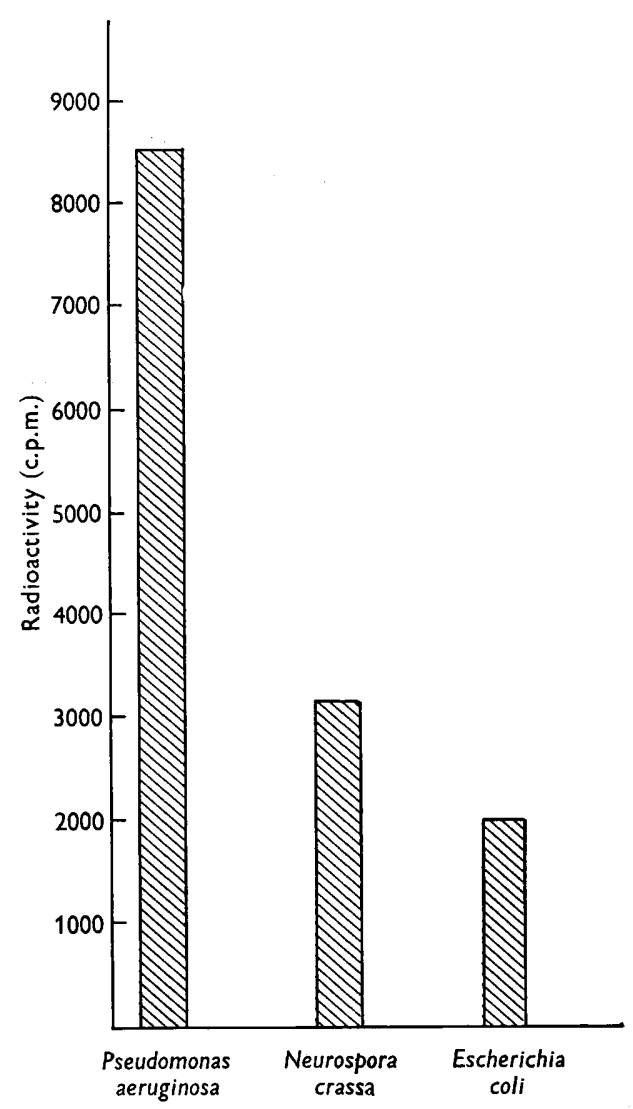

Fig. 3

Fig. 2. Synthesis of $\left[{ }^{14} \mathrm{C}\right]$ spermidine by growing cells of various micro-organisms. The bacteria were grown for $20 \mathrm{hr}$. at $37^{\circ}$, harvested and resuspended in $4.0 \mathrm{ml}$. of medium, supplemented with $3.0 \mathrm{ml}$. of $0.067 \mathrm{M}$-phosphate buffer pH $7.9 ; 2.5 \mu$ mole of $\mathrm{DL}_{-}\left[2-{ }^{14} \mathrm{C}\right]-$ methionine $\left(1.5 \times 10^{5}\right.$ c.p.m.) and incubated for another $14 \mathrm{hr}$. The cells were then harvested, disrupted and the concentration of $\left[{ }^{14} \mathrm{C}\right]$ spermidine in the extracts determined.

Fig. 3. Synthesis of $\left[{ }^{14} \mathrm{C}\right]$ spermidine by cell-free extracts of various micro-organisms. The reaction mixtures contained: $1.0 \mathrm{ml}$. of $0.067 \mathrm{M}$-phosphate buffer $\mathrm{pH} 8.0 ; 1.0 \mu \mathrm{mole}$ of DL- $\left[2-{ }^{14} \mathrm{C}\right]$ methionine $\left(0.6 \times 10^{5}\right.$ c.p.m. $) ; 1.0 \mu$ mole of putrescine; $30 \mu$ mole of $\mathrm{MgSO}_{4}$; $2.5 \mu$ mole of ATP and $3.0 \mathrm{ml}$. of cell-free extract (equiv. of $50 \mathrm{mg}$. of protein). Incubation was carried out at $37^{\circ}$ for $60 \mathrm{~min}$. 


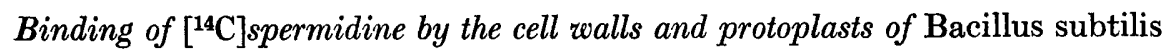

Having established that $\left[{ }^{14} \mathrm{C}\right]$ spermidine was bound to the cell wall of Bacillus subtilis and to a smaller degree to its protoplast, the kinetics of this reaction were studied. Figure 4 shows that cell walls of $B$. subtilis rapidly bound $\left[{ }^{14} \mathrm{C}\right]$ spermidine (prepared biologically by $\boldsymbol{P}$ seudomonas aeruginosa) as indicated by the decrease in radioactivity of the supernatant fluid, and the increase of radioactivity in the precipitate (i.e. cell walls). The binding of $\left[{ }^{14} \mathrm{C}\right]$ spermidine by protoplasts is shown in Fig. 5.

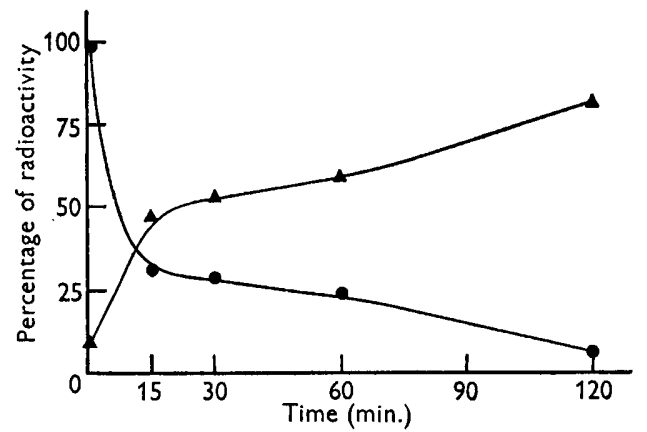

Fig. 4

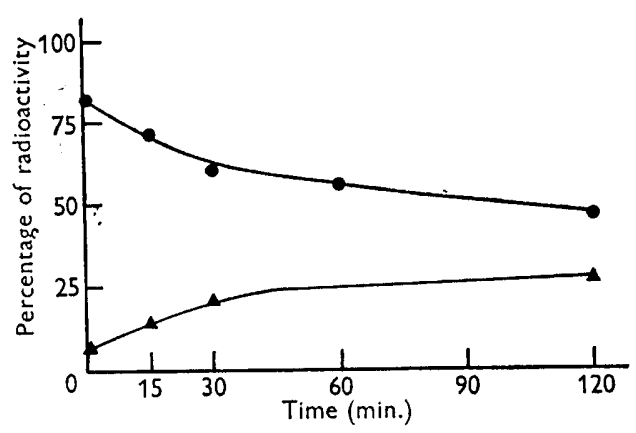

Fig. 5

Fig. 4. Binding of $\left[{ }^{14} \mathrm{C}\right]$ spermidine by cell walls of Bacillus subtilis. The reaction mixture contained $1.0 \mathrm{ml}$. of $\left[{ }^{14} \mathrm{C}\right]$ spermidine $\left(5.0 \times 10^{3} \mathrm{c} . \mathrm{p} . \mathrm{m}\right.$.) and $4.0 \mathrm{ml}$. of cell wall suspension (equiv. of $5.2 \mathrm{mg}$. of protein or $61 \mathrm{mg}$. dry wt.). Samples were taken at the time intervals indicated, centrifuged and the radioactivity of the supernatants, $\bullet$, and the precipitates, $\Delta$, determined.

Fig. 5. Binding of $\left[{ }^{14} \mathrm{C}\right]$ spermidine by protoplasts of Bacillus subtilis. Experimental conditions were as given in Fig. 4, but $4.0 \mathrm{ml}$. of protoplast suspension (equiv. of $10.0 \mathrm{mg}$. of protein or $20 \mathrm{mg}$. dry wt.) was employed. Supernatant; $\Delta$, precipitate.

\section{DISCUSSION}

The amine content of Escherichia coli depends on growth conditions such as the composition and $\mathrm{pH}$ value of the growth medium. In the absence of spermidine in the growth medium, $1 \mathrm{~g}$. wet wt. organism was found to contain about $200 \mu \mathrm{g}$. spermidine (Dubin \& Rosenthal, 1960a). Brewers yeasts contain 130 $\mu$ g. spermidine/g. wet wt. (Fischer \& Bohn, 1957b). These amounts are similar to those found in rat or rabbit livers (Rosenthal \& Tabor, 1956). The use of wet weights of organisms for the comparison of the amounts of spermidine in different organisms, however, might lead to considerable errors. We therefore used the protein content of the examined bacterial extracts as a criterion in the evaluation of our results. The amount of spermidine in the extract is not equal to the total spermidine content of an organism, for insoluble constituents of the cells may retain a considerable amount of this compound which cannot be completely extracted even with $0.1 \mathrm{~N}$-hydrochloric acid (Razin \& Rozansky, 1959). The results represented in Fig. 1 indicate that spermidine is present in similar concentrations in the extracts of the Gram-positive and Gramnegative organisms tested. Extracts of Pseudomonas aeruginosa produced more $\left[{ }^{14} \mathrm{C}\right]$ spermidine from $\left[{ }^{2-{ }^{14}} \mathrm{C}\right]$ methionine than the equivalent extracts of Neurospora crassa and $\boldsymbol{E}$. coli (Fig. 2). The quantities of $\left[{ }^{14} \mathrm{C}\right]$ spermidine which accumulated 
within the organisms grown on $\left[2-{ }^{14} \mathrm{C}\right]$ methionine were smaller than those produced by extracts (Fig. 3). This is not surprising and might be explained by the limited capacity of the whole organism to store the polyamine. Decomposition of spermidine by $\boldsymbol{P}$. aeruginosa (Razin, Gery \& Bachrach, 1959) may also cause a decrease in its intracellular concentration.

The attachment of polyamines to bacteria was described by Razin \& Rozansky (1959), and Mager (1959) studied the binding of spermidine to protoplasts. The receptors on the cell wall might be located in the plastic film of lipoprotein described by Mitchell (1959) or in some bacteria in the lipoprotein particles like those responsible for the adsorption of bacteriophages (Anderson, 1960). The active sites in the protoplasts might be associated with its ribonucleic acid content (Cohen \& Lichtenstein, 1960) or with the cytoplasmic lipoprotein layer (Luria, 1960).

Experiments described in this paper indicate that Bacillus subtilis grown in the presence of methionine or spermidine contained spermidine in cell walls and protoplasts. Cohen $\&$ Lichtenstein (1960) found that polyamines were attached to ribosome particles of Escherichia coli prior to cell disruption, and were not bound during or after the formation of the extract. If this concept is general, one could exclude the possibility of redistribution of the polyamines during the disintegration, and assume that the location of the polyamines in disintegrated and intact cells is the same.

Spermine and spermidine are known to inhibit the growth of various bacteria (Gurevitch, Rozansky, Weber, Brzezinsky \& Eckerling, 1951; Rozansky, Bachrach \& Grossowicz, 1954) and fungi (Razin, Cohen, Rozansky, 1958). As both sensitive and resistant bacteria absorb these polyamines (Razin \& Rozansky, 1959), the selective toxicity is not explained by absorption alone. Detoxification of spermidine by acetylation (Dubin \& Rosenthal, 1960a) does not seem to solve the problem, for acetylated polyamines were also found in Staphylococcus aureus (Rosenthal \& Dubin, 1960), which is sensitive to spermidine. Recent studies on the mode of action of streptomycin indicate that its initial uptake by the bacterial cell occurs outside the cytoplasmic membrane. The secondary uptake is caused by the cytoplasmic membrane, resulting in changes of the cell permeability (Anand \& Davis, 1960). Furthermore, streptomycin-resistant bacteria do not bind streptomycin on their cytoplasmic membrane (Anand, Davis \& Armitage, 1960). Streptomycin resembles spermidine in its basic property; both are bound to acidic components like nucleic acids (Cohen, 1946; Fraser \& Mahler, 1958; Felsenfeld \& Huang, 1960) and their biological activity is counteracted by constituents of serum. One may speculate that the polyamines inhibit the growth of sensitive micro-organisms by interfering with the normal function, synthesis, or permeability barrier, of the cytoplasmic membrane.

The growth-promoting effect of polyamines for certain bacteria (Herbst \& Glinos, 1955; Martin, Pelczar \& Hansen, 1952; Sneath, 1955; Traub, Mager \& Grossowicz, 1955; Kihara \& Snell, 1957) remains still to be explained. The degradation of spermidine to $\beta$-alanine and other compounds by Pseudomonas aeruginosa (Razin, Gery \& Bachrach, 1958, 1959; Bachrach, 1960) and by Mycobacterium smegmatis (Bachrach, Persky \& Razin, 1960) appears to apply to these two micro-organisms and does not explain the growth-promoting activity for other bacteria. It seems possible that polyamines may enhance bacterial growth by affecting the permeability barrier of the cells (e.g. by preventing leakage of nutrients from the cell). Similar effects have been obtained with mitochondria (Tabor, 1960; Herbst \& Whitherspoon, 1960) and bacterial protoplasts (Mager, 1959). 


\section{REFERENCES}

Ames, B. N., Dubin, D. T. \& Rosenthal, S. M. (1958). Presence of polyamines in certain bacterial viruses. Science, 127,814 .

Ames, B. N. \& Dubin, D. T. (1960). The role of polyamines in the neutralization of bacteriophage deoxyribonucleic acid. J. biol. Chem. 235, 769 .

Anand, N. \& Davis, B. D. (1960). Effect of streptomycin on Escherichia coli. Nature, Lond. 185, 22.

Anand, N., Davis, B. D. \& Armitage, A. K. (1960). Uptake of streptomycin by Escherichia coli. Nature, Lond. 185, 23.

Anderson, T. F. (1960). Bacterial viruses-structure and function. The Bacteria, ed. I. C. Gunsalus \& R. Y. Stanier, 1, 409. New York: Academic Press Inc.

Bachrach, U. (1957). The degradation of glycine by Pseudomonas aeruginosa. Biochem. J. 66, 559.

Bachrach, U. (1960). Metabolism of amines. 3. The degradation and synthesis of $\gamma$-aminobutyric acid by Pseudomonas aeruginosa. Biochem. J. 77, 417.

Bachrach, U., Persky, S. \& Razin, S. (1960). Metabolism of amines. 2. The oxidation of natural polyamines by Mycobacterium smegmatis. Biochem. J. 76, 306.

Baker, W., Harborne, J. B. \& Ollis, W. D. (1952). Characterisation of primary aliphatic amines by reaction with $o$-acetoacetylphenol and by paper chromatography. J. chem. Soc. p. 3215.

Bawden, F. C. \& Pirie, N. W. (1959). The infectivity and inactivation of nucleic acid preparations from tobacco mosaic virus. J. gen. Microbiol. $21,438$.

CoHen, S. S. (1946). Streptomycin and desoxyribonuclease in the study of variations in the properties of a bacterial virus. J. biol. Chem. 166, 393.

Cohen, S. S. \& Lichtenstein, J. (1960). Polyamines and ribosome structure. J. biol. Chem. 235, 2112.

Davis, B. D. (1949). The isolation of biochemically deficient mutants of bacteria by means of penicillin. Proc. nat. Acad. Sci., Wash. 35, 1.

Dubin, D. T. \& Rosenthal, S. M. (1960a). The acetylation of polyamines in Escherichia coli. J. biol. Chem. 235, 776.

Dubin, D. T. \& Rosenthal, S. M. (1960b). Polyamine glutathione conjugates in E. coli. Fed. Proc. 19, 1.

Dudley, H. W., Rosenheim, M. C. \& Rosenheim, O. (1924). The chemical constitution of spermine. $I$. The isolation of spermine from animal tissues and the preparation of its salts. Biochem. J. 18, 1263.

Dudley, H. W. \& Rosenheim, O. (1925). Notes on spermine. Biochem. J. 19, 1034.

Dudley, H. W., Rosenheim, O. \& Starling, W. W. (1927). The constitution and synthesis of spermidine, a newly discovered base from animal tissues. Biochem. J. 21, 97.

Felsenfeld, G. \& Huang, S. (1960). The interaction of polynucleotides with metal ions, amino acids and polyamines. Biochem. biophys. Acta, 37, 425.

Fischer, F. G. \& BoHN, H. (1957 a). Die Giftsekrete der Vogelspinnen. Liebigs Ann. 603, 232.

Fischer, F. G. \& BohN, H. (1957b). Über die Bestimmung von Spermin, Spermidin und anderen biogenen Aminen nach papierelektrophoretischer Abtrennung und ihre Mengenverhältnisse in tierischen Organen. Hoppe-Seyl Z. 308, 108.

Fitz-James, P. C. (1958). Studies on the morphology and nucleic acid content of protoplasts of Bacillus megaterium. J. Bact. 75, 369.

Fraser, D. \& MAHLER, H. R. (1958). Effect of diamines on the protoplast infecting agent derived from $T_{2}$ bacteriophage. J. Amer. chem. Soc. 80, 6456.

Giri, K. V., Radhakrishnan, A. N. \& Vaidyanathan, C. S. (1952). A simpler paper chromatographic method for the study of transamination reactions. Nature, Lond. 170, 1025.

GreENe, R. C. (1957). Incorporation of the carbon chain of methionine into spermidine. J. Amer. chem. Soc. 79, 3929.

Gurevitch, J., Rozansky, R., Weber, D., Brzezinsky, A. \& Eckerling, B. (1951). The role of spermine in the inhibition of Staphylococcus aureus by human semen. J. clin. Path. 4, 360. 
Harrison, G. A. (1931). Spermine in human tissues. Biochem. J. 25, 1885.

Herbst, E. J. \& Glinos, E. B. (1955). An analysis of the putrescine requirement of Hemophilus parainfluenzae. J. biol. Chem. 214, 175.

Herbst, E. J., Weaver, R. H. \& Keister, D. L. (1958). The gram reaction and cell composition: diamines and polyamines. Arch. Biochem. Biophys. 75, 171.

Herbst, E. J. \& Whitherspoon, B. H. (1960). Inhibition of spontaneous and induced swelling of mitochondria by spermine. Fed. Proc. 19, 138.

Kinara, H. \& SNeli, E. E. (1957). Spermine and related polyamines as growth stimulants for Lactobacillus casei. Proc. nat. Acad. Sci., Wash. 43, 867.

Kosaki, T., Ikoda, T., Kotani, Y., Nakagawa, S. \& Saka, 'T. (1958). A new phospholipid, malignolipin in human malignant tumors. Science, 127, 1176.

LAYNE, E. (1957). Spectrophotometric and turbidimetric methods for measuring protein. Methods in Enzymology, ed. S. P. Colowick \& N. O. Kaplan, 3, 451. New York: Academic Press, Inc.

LuRIA, S. E. (1960). Bacterial protoplasm-composition and organisation. The Bacteria, ed. I. C. Gunsalus \& R. Y. Stanier, 1, 27. New York: Academic Press Inc.

MAGER, J. (1959). The stabilising effect of spermine and related polyamines and bacterial protoplasts. Biochem. biophys. Acta, 36, 529.

Martin, W. H. Jun., Pelczar, M. J. Jun. \& Hansen, P. A. (1952). Putrescine as a growth requirement for Neisseria. Science, 116, 483.

Mitchell, P. (1959). Biochemical cytology of micro-organisms. Annu. Rev. Microbiol. $13,412$.

Nason, A. \& Evans, H. J. (1953). Triphosphopyridine nucleotide-nitrate reductase in Neurospora. J. biol. Chem. 202, 655.

Razin, S., Cohen, A. \& Rozansky, R. (1958). Antimycotic effect of spermine. Proc. Soc. exp. Biol., N.Y. 99, 459.

Razin, S., Gery, I. \& Bachrach, U. (1958). Formation of $\beta$-alanine from spermine and spermidine by Pseudomonas aeruginosa. Nature, Lond. 181, 700.

RAZIN, S., Gery, I. \& BAChraCh, U. (1959). The degradation of natural polyamines and diamines by bacteria. Biochem. $J .71,551$.

Razin, S. \& Rozansky, R. (1959). Mechanism of the antibacterial action of spermine. Arch. Biochem. Biophys. 81, 36.

Rosenthal, S. M. \& Dubin, D. T. (1960). Acetylation of polyamines by Staphylococcus. Fed. Proc. 19, 2.

Rosenthal, S. M. \& TABor, C. W. (1956). The pharmacology of spermine and spermidine, distribution and excretion. J. Pharmacol. 116, 131.

Rozansky, R., Bachrach, U. \& Grossowicz, N. (1954). Studies on the antibacterial action of spermine. J. gen. Microbiol. 10, 11.

Salton, M. R. J. \& Horne, R. W. (1951). Studies of the bacterial cell wall. 2. Methods of preparation and some properties of cell walls. Biochim. biophys. Acta, 7, 177.

SNEATH, P. H. A. (1955). Putrescine as an essential growth factor for a mutant of Aspergillus nidulans. Nature, Lond. 175, 818.

TABOR, C. W. (1960). The stabilizing effect of spermine and related amines on mitochondria and protoplasts. Biochem. biophys. Res. Comm. 2, 117.

Tabor, H., Rosenthal, S. M. \& TABor, C. W.(1957). The role of putrescine and methionine in the enzymatic synthesis of spermidine in Escherichia coli extracts. J. Amer. chem. Soc. 79, 2978.

Tabor, H., Rosenthal, S. M. \& Tabor, C. W. (1958). The biosynthesis of spermidine and spermine from putrescine and methionine. J. biol. Chem. 233, 907.

TABOR, H. \& TABOR, C. W. (1960). Further purification of the enzymes concerned with the biosynthesis of spermidine in E. coli. Fed. Proc. 19, 6.

Traub, A., Mager, J. \& Grossowicz, N. (1955). Studies on the nutrition of Pasteurella tularensis. J. Bact. 70, 60 .

Weaver, R. H. \& Herbst, E. J. (1958). Metabolism of diamines and polyamines in microorganisms. J. biol. Chem. 231, 637. 